\title{
Risk Stratification with Troponin I in Patients Undergoing Myocardial Revascularization Surgery
}

\author{
João Carlos Ferreira Leal, Alfredo de Paula Neto, Luis Ernesto Avanci, \\ Maria Cristiane Valéria Braga Braile, Moacir Fernandes de Godoy, Domingo Marcolino Braile \\ São José do Rio Preto, SP - Brazil
}

\begin{abstract}
Objective - To determine the immediate behavior and the prognostic value in terms of late survival of serum troponin Imeasurement in patients undergoing myocardial revascularization surgery with extracorporeal circulation.
\end{abstract}

Methods - We studied 88 random patients, 65 (73.8\%) of the male sex, who underwent myocardial revascularization surgery with extracorporeal circulation. Troponin measurements were performed as follows: in the preoperative period, right after intensive care unit admission, and on the first and second postoperative days. Values below 0.1 nanogram per milliliter $(\mathrm{ng} / \mathrm{mL})$ were considered normal. The cut points for late prognostic assessment were $0.5 \mathrm{ng} /$ $m L ; 1 \mathrm{ng} / \mathrm{mL} ; 2.5 \mathrm{ng} / \mathrm{mL}$; and $5 \mathrm{ng} / \mathrm{mL}$.

Results - The serum troponin I levels were elevated on the first postoperative day, suggesting the occurrence of specific myocardial damage. Patients with a poor prognosis could be identified, because the serum levels above $2.5 \mathrm{ng} / \mathrm{mL}$ and $5 \mathrm{ng} / \mathrm{mL}$ in the postoperative period resulted, respectively, in mortality rates of $33 \%$ and $50 \%$ in a maximum 6-month follow-up.

Conclusion - Troponin I values around $2.5 \mathrm{ng} / \mathrm{mL}$ in the postoperative period should call attention to the need for more aggressive diagnostic or therapeutical measures.

Keywords: troponin I, myocardial revascularization, cardiac marker

Braile Cardiocirurgia - Hospital Infante Dom Henrique da Sociedade Portuguesa de Beneficência.

Mailing address: João Carlos Ferreira Leal - Rua Luís de Camões, 3111 - 15051200 - São José do Rio Preto, SP, Brazil - E-mail: joaocarlos@braile.com.br English version by Stela Maris C. e Gandour
Recently, the troponins have received increasing attention as highly specific markers in acute myocardial infarction ${ }^{1,2}$. In patients with acute myocardial infarction, elevation of the creatine phosphokinase activity above normal values is rarely found within 4 to 6 hours after pain onset, and, therefore, early diagnosis strongly depends on typical electrocardiographic alterations, which is a problem due to the fact that the electrocardiogram is inconclusive in up to $40 \%$ of the patients. Troponin I and troponin $\mathrm{T}$ become measurable 3 to 4 hours after the beginning of acute myocardial infarction. Studies about the levels of troponin T measured in small groups of selected patients with precordial pain within the first 24 hours after admission have reported an excess of cardiac events in those with elevated troponin T levels, even in the absence of elevation in CK-MB ${ }^{3}$.

Most cardiac surgeries require the heart to remain static and without blood while the procedure is being performed. For this, the extracorporeal circulation circuits, which provide cardiac and pulmonary support during surgery, are used. It has been well documented that, during this cardiac arrest period, the heart undergoes a controlled ischemic process that culminates in greater or smaller myocardial damage. This is the reason for the use of cardioprotective solutions during cardioplegia, in an attempt to minimize the consequences on cardiac function. The diagnosis of perioperative acute myocardial infarction is often difficult due to patient's sedation and intubation, which prevent the verbal communication of symptoms, and the low sensitivity and specificity provided by the regular electrocardiographic monitors, which are usually restricted to 1 or 2 leads. Mair et $\mathrm{al}^{4}$ used troponin I to assess the occurrence of perioperative acute myocardial infarction in patients undergoing myocardial revascularization with saphenous vein bypass grafting, and showed that troponin I is an excellent marker to assess myocardial ischemia during cardiac surgeries.

In Brazil, clinical and surgical studies involving the measurement of serum troponin to assess myocardial damage are still scarce, which motivated this study. The objecti- 
ve of this study was to determine the immediate behavior and the prognostic value in terms of late survival of the measurement of serum troponin I in patients undergoing myocardial revascularization with extracorporeal circulation.

\section{Methods}

We studied 88 random patients, $65(73.9 \%)$ males, who underwent myocardial revascularization with extracorporeal circulation circuit, using the cardioplegia technique with continuous anterograde/retrograde tepid low-volume blood protection ${ }^{5}$.

The duration of extracorporeal circulation ranged from 31 to 165 minutes, with mean and standard deviation of $76.4 \pm 24.4$ minutes, and median of 72 minutes. The total duration of myocardial ischemia ranged from 4 to $36 \mathrm{minu}-$ tes, with mean and standard deviation of $16.8 \pm 7$ minutes, and median of 15 minutes.

Troponin I was measured in the following moments: preoperative period; on patient's admission to the intensive care unit (ICU); once a day, in the morning, on the first postoperative day.

The method used to measure troponin I was chemoluminescence with the Acess device from Sanofi-Pasteur; values below 0.1 nanograms per milliliter $(\mathrm{ng} / \mathrm{mL})$ were considered normal.

The patients were postoperatively assessed, and their evolution in months was recorded aiming at determining the survival rates. The outcome considered relevant was death due to ischemia, arrhythmia, or congestive heart failure. Mean, standard deviation, confidence interval, and median were calculated. To assess the prognostic values of serum troponin I, the following cut points were adopted: $0.5 \mathrm{ng} / \mathrm{mL}, 1 \mathrm{ng} / \mathrm{mL}, 2.5 \mathrm{ng} / \mathrm{mL}$, and $5 \mathrm{ng} / \mathrm{mL}$, and the relative risk and $95 \%$ confidence interval were calculated for each situation. Actuarial curves (Kaplan-Meier) were used to study long-term survival, and the results were compared by a log-rank test or hazard rate with a $95 \%$ confidence interval. The actuarial curves were performed with the aid of the Graphpad Prism statistical program. An alpha error of 5\% was admitted, and p values below 0.05 were considered significant.

\section{Results}

Serum troponin I values in median are shown in table I. The values are presented in median, because it was not a Gaussian distribution.

As noted in the "Method" section, 4 cut points were adopted for serum troponin I $(0.5 \mathrm{ng} / \mathrm{mL} ; 1 \mathrm{ng} / \mathrm{mL} ; 2.5 \mathrm{ng} /$ $\mathrm{mL}$; and $5 \mathrm{ng} / \mathrm{mL}$ ) to serve as a basis in the prognostic evaluation of troponin I in regard to the event death throughout evolution.

The duration of extracorporeal circulation and the total duration of ischemia were correlated with serum troponin I levels, because it was relevant to the adequate further interpretation of the results (fig. 1 to 4 ).
Information about the late evolution of the patients in regard to the event death allowed the correlation with serum troponin I levels of the acute postoperative phase, aiming at establishing the prognostic value. The patients were followed up for a mean period of $9.3 \pm 6.3$ months (median of 10 months), which ranged from 0 to 17 months.

Five patients died, which resulted in an overall mortality of 5.6\%. Two patients died on the eighth day of followup, 2 others in the fourth month of follow-up, and another patient in the sixth month of follow-up (chart I).

Because 1 of the objectives of the study was to investigate the late prognostic value of the serum troponin I levels, the actuarial curve of survival was constructed,

\begin{tabular}{|l|llll|}
\hline \begin{tabular}{|} 
Table I - Results of serum troponin I (median) in the preoperative \\
period, on ICU admission, and on the first postoperative day, in \\
nanograms per milliliter, in the $\mathbf{8 8}$
\end{tabular} \\
\hline $\begin{array}{c}\text { Pre } \\
\text { operative }\end{array}$ & $\begin{array}{c}\text { ICU } \\
\text { admission }\end{array}$ & $\begin{array}{c}\text { 1st PO } \\
\text { day }\end{array}$ & $\begin{array}{c}\text { 2nd PO } \\
\text { day }\end{array}$ \\
\hline Median $(\mathrm{ng} / \mathrm{mL})$ & 0.02 & 0.41 & 0.55 & 0.39 \\
\hline
\end{tabular}

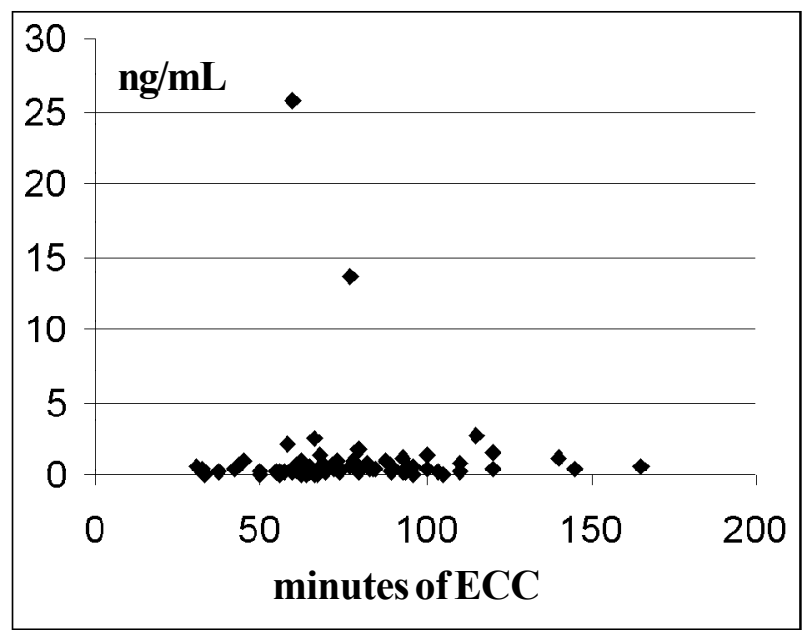

Fig. 1 - Correlation between duration of extracorporeal circulation and serum troponin I levels (in nanograms per milliliter) on ICU admission.

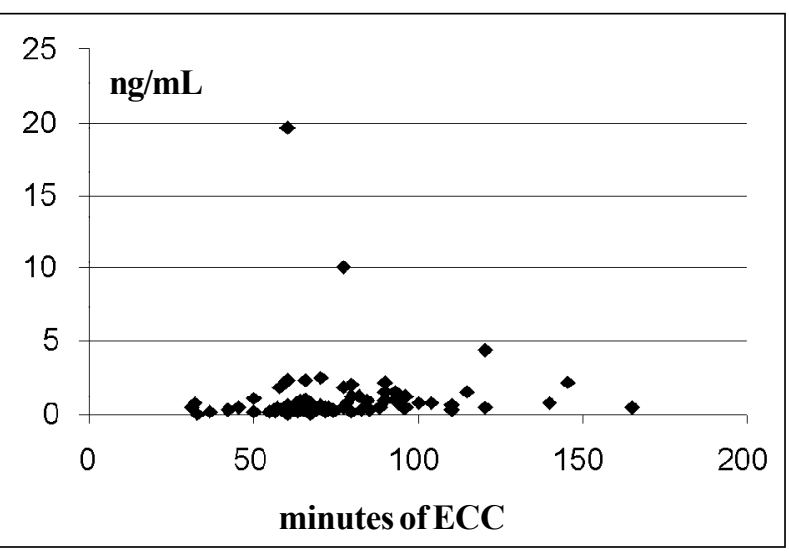

Fig. 2 - Correlation between duration of extracorporeal circulation and serum troponin I levels (in nanograms per milliliter) on the first postoperative day. 


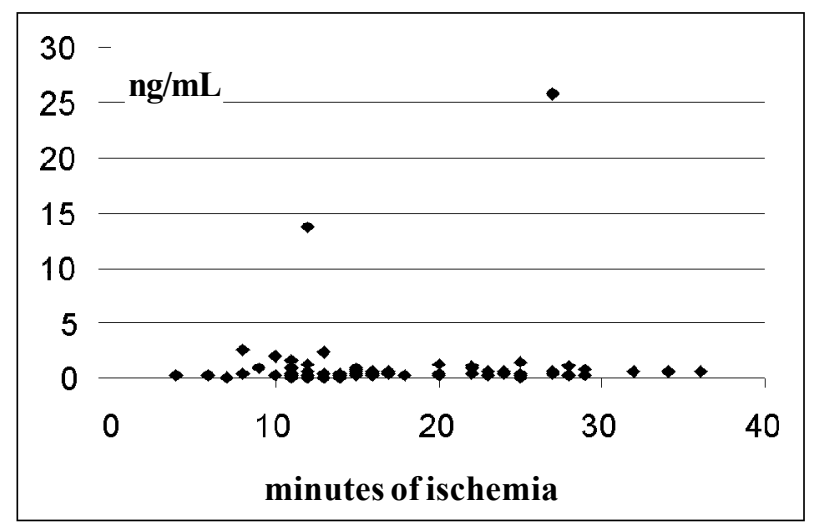

Fig. 3 - Correlation between duration of ischemia and serum troponin I levels (in nanograms per milliliter) on ICU admission.

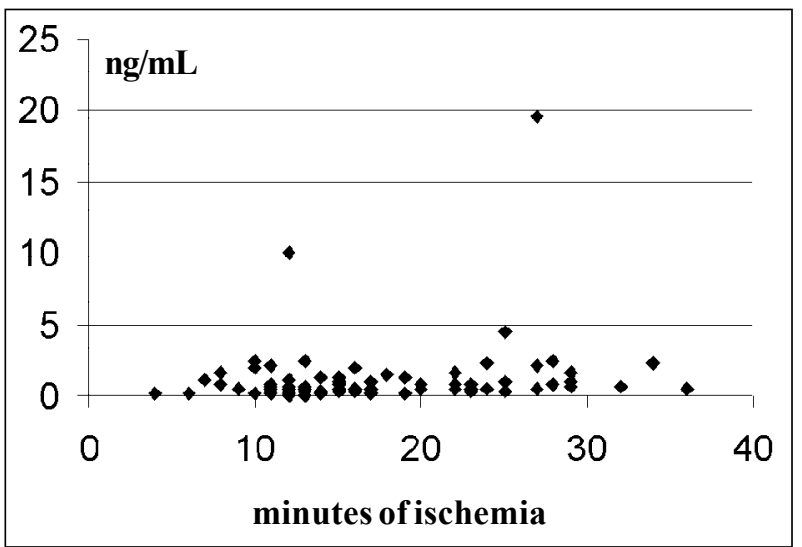

Fig. 4 - Correlation between duration of ischemia and serum troponin I levels (in nanograms per milliliter) on the first postoperative day.

according to the cut points established. The correlations were performed with the troponin I levels on the first postoperative day (PO1), because these were usually the greatest values obtained. Figures 5 to 8 depict the findings of this evaluation, respectively, for the cut points $0.5 \mathrm{ng} / \mathrm{mL}$, $1 \mathrm{ng} / \mathrm{mL}, 2.5 \mathrm{ng} / \mathrm{mL}$, and $5 \mathrm{ng} / \mathrm{mL}$.

A significant difference was found between the survival curves from the $2.5-\mathrm{ng} / \mathrm{mL}$ cut point of serum troponin I on.

The data regarding the relative risk of death over the postoperative evolution period according to the cut points of serum troponin I are shown in table II.

Once again, the $2.5-\mathrm{ng} / \mathrm{mL}$ cut point of troponin I on

\begin{tabular}{|c|c|c|}
\hline \multicolumn{3}{|c|}{$\begin{array}{l}\text { Chart I - Percentage of death over the follow-up period in regard to } \\
\text { the cut point of serum troponin I levels, in nanograms/milliliter, on } \\
\text { the first postoperative day }\end{array}$} \\
\hline $\begin{array}{l}\text { Cut point of } \\
\text { serum troponin I } \\
(\mathrm{ng} / \mathrm{mL})\end{array}$ & $\begin{array}{c}\text { Mortality over the } \\
\text { follow-up period }(\%)\end{array}$ & Time of death \\
\hline Up to 0.5 & $3.5 \%$ & 4 months/4 months \\
\hline$>1.0$ & $12 \%$ & 8 days \\
\hline$>2.5$ & $33.3 \%$ & 8 days \\
\hline$>5.0$ & $50 \%$ & 6 months \\
\hline
\end{tabular}

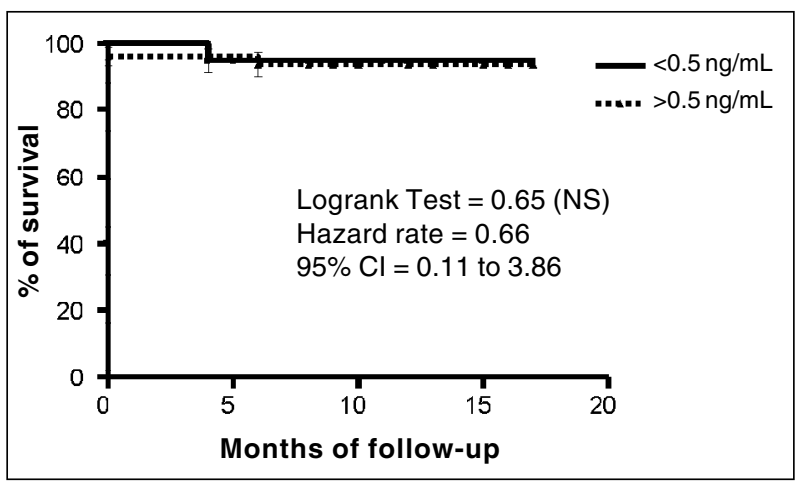

Fig. 5 - Survival curve (Kaplan-Meier) for the entire group up to 17 months of follow-up according to serum troponin I levels on the first postoperative day at the cut point of $0.5 \mathrm{ng} / \mathrm{mL}$.

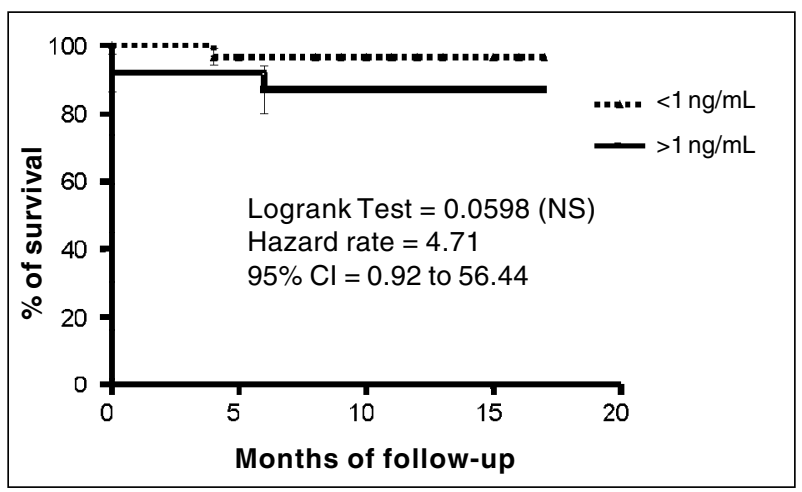

Fig. 6 - Survival curve (Kaplan-Meier) for the entire group up to 17 months of followup according to serum troponin I levels on the first postoperative day at the cut point of $1 \mathrm{ng} / \mathrm{mL}$.

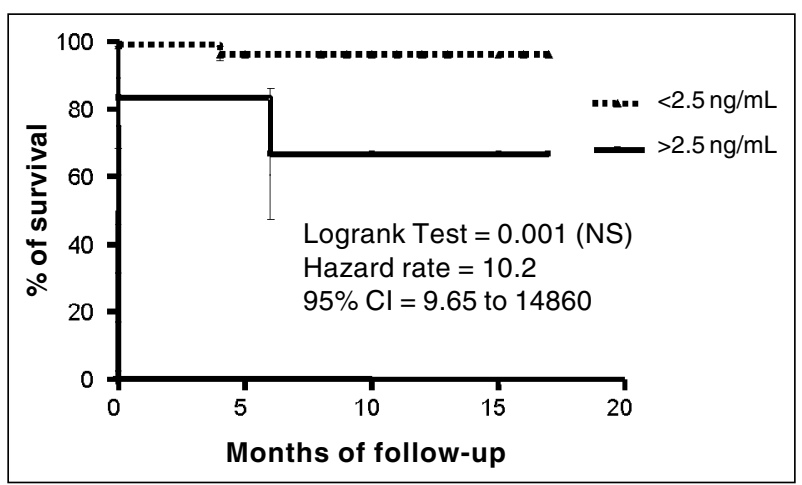

Fig. 7 - Survival curve (Kaplan-Meier) for the entire group up to 17 months of followup according to serum troponin I levels on the first postoperative day at the cut point of $2.5 \mathrm{ng} / \mathrm{mL}$.

the first postoperative day of myocardial revascularization enabled the identification of a group of patients with a significantly greater risk of evolving to death within 17 months of follow-up.

\section{Discussion}

The serum troponin I levels, both on ICU admission and on the first postoperative day, were very elevated, suggesting a harmful effect (relative ischemia) due to the artifi- 


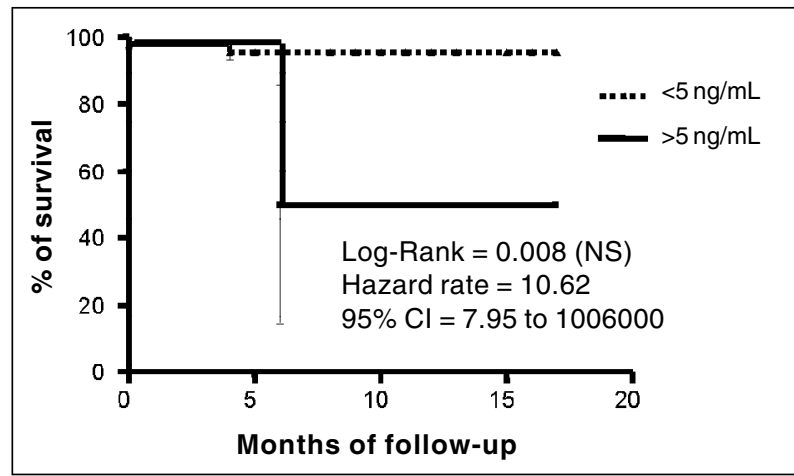

Fig. 8 - Survival curve (Kaplan-Meier) for the entire group up to 17 months of followup according to serum troponin I levels on the first postoperative day at the cut point of $5 \mathrm{ng} / \mathrm{mL}$.

\begin{tabular}{|c|c|c|c|}
\hline \multicolumn{4}{|c|}{$\begin{array}{c}\text { Table II - Relative risk of death in regard to the cut points for serum } \\
\text { troponin I, in nanograms per } \mathrm{mL} \text {, in the } 88 \text { patients who underwent } \\
\text { myocardial revascularization surgery }\end{array}$} \\
\hline $\begin{array}{l}\text { Cut point } \\
(\mathrm{ng} / \mathrm{mL})\end{array}$ & $\begin{array}{c}\text { Mortality } \\
(\%)\end{array}$ & Relative risk & $95 \% \mathrm{CI}$ \\
\hline$>0.5$ versus $<0.5$ & $5.9 \times 3.7$ & 1.59 & $0.28-9.12$ \\
\hline$>1.0$ versus $<1.0$ & $12.0 \times 2.5$ & 4.80 & $0.85-27.13$ \\
\hline$>2.5$ versus $<2.5$ & $33.3 \times 3.0$ & 11.00 & $2.25-53.84^{*}$ \\
\hline$>5.0$ versus $<5.0$ & $50.0 \times 3.9$ & 12.88 & $2.38-69.52^{*}$ \\
\hline
\end{tabular}

cial perfusion of the heart, even considering myocardial protection with the modified cardioplegic solution. In addition, no correlation was observed between the duration of extracorporeal circulation or the duration of ischemia and the measurements of serum troponin I. This may show that the major element to determine the elevation in troponin I is not extracorporeal circulation per se, but the occurrence or not of a more significant ischemic impairment (myocardial necrosis due to occlusion of or prolonged decreased flow in the native coronary artery, occlusion of the bypass graft, embolic event, etc). Hirsch et $\mathrm{al}^{6}$ studied the pattern and the potential value of troponin I elevation after cardiac surgery in children with congenital heart disease, and also reported high values on ICU admission. The authors related those values to the extension of myocardial damage resulting both from incisional injury and from intraoperative factors, such as aortic clamp and extracorporeal circulation.

After the return of the normal heart beats, a phenomenon similar to that observed in infarcted patients undergoing successful thrombolysis occurs: an early elevation in enzymatic levels, because they are rapidly carried to the systemic circulation due to tissue perfusion.

The serum troponin I levels (in nanograms per milliliter) on the first postoperative day in the 5 patients who died were as follows: $0.1 ; 0.14 ; 1.53 ; 3.42 ;$ and $10.01 \mathrm{ng} / \mathrm{mL}$. In 3 patients, those levels were extremely elevated (15 times, 34 times, and 100 times the normal level).

Lüscher et $\mathrm{al}^{7}$ had already tried to determine the applicability of troponins $\mathrm{T}$ and I to stratify the risk of the patien- ts with unstable coronary artery disease, and concluded that both provide independent prognostic information in regard to cardiac death and myocardial infarction. To those authors, the predictive capacity of the markers varied according to the cut points, but was already significant with values of $0.05 \mu \mathrm{g} / \mathrm{L}$ for troponin $\mathrm{T}$ and $1.5 \mu \mathrm{g} / \mathrm{L}$ (the same as $1.5 \mu \mathrm{g} / \mathrm{mL}$ ) for troponin I. Those authors stated that prospective studies might be able to indicate whether troponin $T$ and troponin I can identify patients who may benefit from the antithrombotic treatment or invasive procedures, or both.

Mair et al ${ }^{4}$ used troponin I to assess the occurrence of perioperative myocardial infarction in patients undergoing myocardial revascularization with saphenous vein bypass graft. Troponin I increased in 22 of the 26 elective patients, who showed no clinical or laboratory evidence of myocardial infarction. The baseline value in these patients was $1.7 \pm 1 \mu \mathrm{g} / \mathrm{L}$. Two of the 22 patients with no perioperative infarction showed troponin I levels greater than $3 \mu \mathrm{g} / \mathrm{L}(3.9$ and $3.4 \mu \mathrm{g} / \mathrm{L}$ ), indicating a more significant myocardial impairment than that observed in the other 20 patients, but with no significant elevation in CK-MB. Four of the 26 elective patients had electrocardiographic, echocardiographic, and enzymatic findings (CK-MB) of perioperative infarction. One of them with Q infarction had a troponin I peak of approximately $30 \mu \mathrm{g} / \mathrm{L}$, and 3 patients with non-Q infarction had troponin I levels around $5 \mu \mathrm{g} / \mathrm{L}$. Those authors suggested that, after elective myocardial revascularization surgeries, troponin I peaks greater than $3.7 \mu \mathrm{g} / \mathrm{L}$, concentrations greater than $3.1 \mu \mathrm{g} / \mathrm{L}$ after 12 hours, or concentrations around $2.5 \mu \mathrm{g} / \mathrm{L}$ after 24 hours indicate a high probability of perioperative myocardial infarction.

Our data are very similar to those in the literature, and, in our opinion, they seem to present sufficient evidence to indicate early intervention (cineangiographic restudy, eventual surgical reintervention or intensive outpatient care unit follow-up) in patients with serum troponin I levels above $2.5 \mathrm{ng} / \mathrm{mL}$ on the first postoperative day.

To correlate the findings of elevated levels of troponin I with elevated levels of enzymes, such as CK-MB, was not an objective of our study. The alterations in CK-MB are already very well known, and, in addition, the times of elevation and maintenance in circulation of CK-MB levels are very different from those of troponin I, which makes the comparison very difficult and unproductive.

In our understanding, the cost of troponin I measurement, although greater than that of CK-MB, is not enough of a hindrance to its routine use, because it does not require the concomitant measurement of other markers of myocardial damage, as we have already shown in our case series. In addition, frequent and serial measurements are not necessary, because the isolated measurement on the first postoperative day is enough to select high-risk subgroups.

In conclusion, measurement of troponin I in patients undergoing myocardial revascularization surgery showed a characteristic immediate behavior with an important elevation in its serum concentration on ICU admission and on the 
first postoperative day. No correlation was observed with the duration of ischemia or the duration of extracorporeal circulation, suggesting that troponin I elevation is due to a specific myocardial damage (native coronary obstruction, bypass occlusion, etc) and not to extracorporeal circulation or the total time of ischemia.

It was possible to determine that the cut points establi- shed separate the patients with a poor prognosis, because values greater than $2.5 \mathrm{ng} / \mathrm{mL}$ or $5 \mathrm{ng} / \mathrm{mL}$ on the first postoperative day resulted in mortality rates of $33 \%$ and $50 \%$ within the first 6 months of follow-up. Therefore, troponin I levels around $2.5 \mathrm{ng} / \mathrm{mL}$ on the first postoperative day should call attention to the need for more aggressive diagnostic or therapeutic measures.

\section{References}

1. Mair J. Cardiac troponin I and troponin T: are enzymes still relevant as cardiac markers? Clin Chim Acta 1997; 257: 99-115.

2. Godoy MF, Braile DM, Purini Neto J. A troponina como marcador de injúria celular miocárdica. Arq Bras Cardiol 1998; 71: 629-33.

3. Ohman EM, Armstrong PW, Christenson RH, et al. Cardiac troponin T levels for risk stratification in acute myocardial ischemia. N Engl J Med 1996; 335 : 1333-41.

4. Mair J, Larue C, Mair P, Balogh D, Calzolari C, Puschendorf B. Use of cardiac troponin I to diagnose perioperative myocardial infarction in coronary artery bypass grafting. Clin Chem 1994; 40(11 Pt 1): 2066-70.

5. Braile DM. Cardioplegia isotérmica anterógrada/retrógrada de baixo volume (apostila, 1997).

6. Hirsch R, Dent CL, Wood MK, et al. Patterns and potential value of cardiac troponin I elevations after pediatric cardiac operations. Ann Thorac Surg 1998; 65: 1394-9.

7. Lüsher MS, Thygesen K, Ravkilde J, Heickendorff L. Applicability of cardiac troponin $\mathrm{T}$ and I for early risk stratification in unstable coronary artery disease. Circulation 1997; 96: 2578-85. 